\title{
John Locke, Adam Smith and Karl Marx's Critique of Private Property
}

There are two opposing interpretations of John Locke's Two Treatises on Government $^{1}$ that are relevant from the point of view of Marx's critical presentation. Macpherson $^{2}$ interpreted Locke as having provided a justification of private property and the accumulation of capital. Tully's ${ }^{3}$ analysis of Locke's theory was an explicit critique of Macpherson's interpretation. In Locke's theory, there is no place either for private property or for the accumulation of capital. On the contrary, in Tully's opinion, Locke provided a justification for common property and the individuation of property not to be mixed with private property.

Locke's analysis of property begins with the statement that land and its products are originally given to humankind to be used in common:

Whether we consider natural Reason, which tells us, that Men, being once born, have a right to their Preservation, and consequently to Meat and Drink, and such other things, as Nature affords for their Subsistence: Or Revelation, which gives us an account of those Grants God made of the world to Adam, and to Noah, and his Sons, 'tis very clear, that God, as King David says, Psalm CXv, xvi has given the Earth to the Children of Men, given it to Mankind in common. ${ }^{4}$

If land and all the products of land are given by God to all of humankind in common, how, then, can anyone have property in anything and even without the explicit consent of all the other members of the society? This is the problem Locke set out to solve in his Treatise. The 'deduction', as Locke says, 'is as follows': 'every Man has a Property in his own Person ... The Labour of his Body, and the Work of his Hands, we may say, are properly his'. ${ }^{5}$

The only way to appropriate things from nature legitimately is through one's own labour: 'Whatsoever then he removes out of the State that Nature

\footnotetext{
Locke 1965.

2 Macpherson 1972.

3 Tully 1980.

4 Locke 1965, p. 327.

5 Locke 1965, pp. 328-9.
} 
hath provided, and left it in, he hath mixed his Labour with, and joyned to it something that is his own, and thereby makes it his Property'. ${ }^{6}$ Because labour adds to nature something which unquestionably belongs to the labourer, things are mixed, so to say, with his labour, and hence become his property. The right to private property, the right to appropriate something from nature that was originally given to all people in common, is based on labour, and only labour. There are, however, two important limitations regulating the appropriation of property. The first restriction explicitly states that every person has a right to the products of their labour only insofar as there is enough left for everybody else to take for the preservation of their own life:

For this Labour, being the unquestionable Property of the Labourer, no Man but he can have a right to what that is once joyned to, at least where there is enough, and as good left in common to others. ${ }^{7}$

The second limitation is the spoilage limitation: no one has a right to more than one - or one's dependants - can personally make use of or consume before it spoils:

As much as any one can make use of to any advantage of life before it spoils; so much he may by his labour fix a Property in. Whatever is beyond this, is more than his share, and belongs to others. Nothing was made by God for Man to spoil or destroy. ${ }^{8}$

Property in land is principally acquired in the same manner as in the products of land: 'As much Land as a Man Tills, Plants, Improves, Cultivates, and can use the Product of, so much is his Property. ${ }^{9}$ The same limitation applying to the products of land is also valid with regard to the appropriation of landed property: so long as there is enough land of equal quality left for others to cultivate, everyone has a right to the land he cultivates. ${ }^{10}$

Because of the limitations imposed on property, no one can appropriate more than they can add their labour to, and no more than they can use for their own convenience:

$\begin{array}{ll}6 & \text { Locke } 1965, \text { p. } 329 . \\ 7 & \text { Ibid. } \\ 8 & \text { Locke 1965, p. } 322 . \\ 9 & \text { Ibid. } \\ 10 & \text { Locke 1965, p. } 333 .\end{array}$ 
The Measure of Property, Nature has well set, by the Extent of Men's Labour, and the Conveniency of Life: No Man's Labour could subdue, or appropriate all ... This measure did confine every Man's Possession, to a very moderate Proportion. ${ }^{11}$

The introduction of money, however, changes the original rules regulating the appropriation of property. By agreeing on the use of money, people make it possible to appropriate larger possessions, which would, in fact, violate the original limitations regulating private possessions:

That the same Rule of Propriety, ... that every Man should have as much as he could make use of, would hold still in the World, without straining any body, since there is Land enough in the World to suffice double the Inhabitants had not the Invention of Money, and the tacit Agreement of Men to put a value on it, introduced (by Consent) larger Possessions, and a Right to them; which, how it has done, I shall, by and by, shew more at large. ${ }^{12}$

The introduction of money is thus the first contract agreed upon by the inhabitants in the original state of nature, the second being the introduction of political power. The introduction of money by the common consent of the members of society changes the original rule of property; the spoilage limitation can be overcome by introducing money which concretely - in the form of gold and silver - does not spoil or decay, thus making possible the hoarding of money and larger possessions without violating this restriction:

And thus came in the use of Money, some lasting thing that Men might keep without spoiling, and that by mutual consent Men would take in exchange for the truly useful, but perishable Supports of Life. ${ }^{13}$

The tacit agreement to use money and put value on it also, out of necessity, entails agreement on unequal possessions:

But since Gold and Silver, being little useful to the Life of Man in proportion to Food, Rayment, and Carriadge, has its value only from the consent of Men, it is plain that Men have agreed to disproportionate and

\footnotetext{
11 Locke 1965 , p. 334.

12 Locke 1965 , p. 335.

13 Locke 1965 , p. 343 .
} 
unequal Possession on the Earth, they having by a tacit and voluntary consent found out a way, how a man may fairly possess more land than he himself can use the product of, by receiving in exchange for the overplus, Gold and Silver, which may be hoarded up without injury to any one, these metals not spoileing or decaying in the hands of the possessor. This partage of things, in an inequality of private possessions, men have made practicable out of the bounds of Societie, and without compact, only by putting a value on gold and silver and tacitly agreeing in the use of Money. ${ }^{14}$

However, the second limitation, the sufficiency rule, is more problematic. Locke was quite explicit that with the introduction of money, people can have a right to larger possessions and thus they would not, in fact, leave enough for others to make use of.

According to Macpherson, ${ }^{15}$ Locke was faced with the dilemma of at least two seemingly contradictory rules regulating the right to property, the right based on one's own labour under the limitations of the sufficiency rule, and the accumulation of money which obviously violates the sufficiency rule, even if it overcomes the spoilage rule. Locke solved the contradiction caused by the introduction of money and legitimated the larger possessions by modifying his original sufficiency limitation; the private appropriation of landed property is shown to be in common benefit of humankind; the productivity of labour under private property yields a much higher produce than land lying in waste:

he who appropriates land to himself by his labour, does not lessen but increase the common stock of mankind. For the provisions serving to the support of humane life, produced by one acre of inclosed and cultivated land, are (to speak much within compasse) ten times more, than those, which are yielded by an acre of Land, of an equal richnesse, lyeing wast in common. ${ }^{16}$

The accumulation of property is then legitimated by the fruits of labour used in larger possessions:

\footnotetext{
14 Locke 1965, p. 344.

15 Macpherson 1972.

16 Locke 1965, p. 336.
} 
For I ask whether in the wild woods and uncultivated wast of America left to Nature, without any improvement, tillage or husbandry, a thousand acres will yeild the needy and wretched inhabitants as many conveniences of life as ten acres of equally fertile land in Devonshire where they are well cultivated? ${ }^{17}$

As Macpherson ${ }^{18}$ has pointed out, this argument was added only in the third edition of Locke's Treatise. Macpherson summarised Locke's 'astonishing achievement' of solving the seemingly contradictory presumptions of his theory as follows:

The chapter on property, in which Locke shows how the natural right to property can be derived from the natural right to one's life and labour, is usually read as if it were simply the supporting argument for the bare assertion offered at the beginning of the Treatise that every man had a natural right to property 'within the bounds of the Law of Nature'. But in fact the chapter on property does something much more important: it removes 'the bounds of the Law of Nature' from the natural property right of the individual. Locke's astonishing achievement was to base the property right on natural right and natural law, and then to remove all the natural law limits from the property right. ${ }^{19}$

Locke's main legitimatory argument is that even 'if there is not then enough and as good land left for the others, there is enough and as good (indeed a better) living left for others. And the right of all men to a living was the fundamental right from which Locke had in the first place deduced their right to appropriate land. ${ }^{20}$

To Locke, the purpose of money was not merely to facilitate the exchange of things produced for consumption,

that is, to enlarge, beyond the scale of barter, exchange between producers of goods intended for consumption. The characteristic purpose of money is to serve as capital. Land itself Locke sees as merely a form of capital ... He identifies money and capital, and assimilates both to land. ${ }^{21}$

\footnotetext{
17 Ibid.

18 Macpherson 1972, p. 211, n. 4.

19 Macpherson 1972, p. 199.

$20 \quad$ Macpherson 1972, p. 212.

21 Macpherson 1972, p. 206.
} 
The purpose of agriculture, industry and commerce was the accumulation of capital, not to provide consumable income for its owner, but to beget further capital by profitable investment. ${ }^{22}$ Machpherson's conclusion, then, is that Locke justified the specifically capitalistic appropriation of land and money. And the accumulation of capital is justified by Locke in the state of nature prior to the consent of civil society. ${ }^{23}$

Macpherson further argued that the fact that the accumulation of capital is read all the way back to the state of nature is further supported by Locke's assumption of a wage relationship existing in the state of nature. ${ }^{24}$ The labour limitation supposed by Locke says that anyone is entitled to appropriate only as much as one has mixed one's labour with. Only if one assumes that the wage relationship exists in the state of nature does it become possible to overcome the labour limitation; if the labour is the property of the labourer, it becomes fully alienable and exchangeable as a property in its bourgeois sense: 'The labour thus sold becomes the property of the buyer, who is then entitled to appropriate the produce of that labour.'.25

In his study A Discourse on Property, James Tully ${ }^{26}$ showed that there is no place for private property or for the wage labour relationship in Locke's Two Treatises, meaning that Macpherson's interpretation is ungrounded. Locke did not justify private property - even less the accumulation of capital. In Locke's theory, money is simply hoarded and it is the miser's desire to hoard money, which Locke not only disapproved of but even regarded as unnatural.

22 Macpherson 1972, p. 207.

23 Macpherson 1972, pp. 208-9.

24 Rainer Rotermundt further radicalised Macpherson's interpretation of Locke's theory: Locke read back into the state of nature both the use of money as capital and the wage labour relationship, and the contrary assumption of private property which is based only on one's own labour. These contrary assumptions follow from the identification of relations to nature with social relations. The incentive to accumulate follows in Locke's analysis exclusively from the introduction of money, and money is identified with capital. Capital is thus identified with the natural properties of both money and land (see Rotermundt 1976, pp. 98-9). Thus, both the generalisation of commodity relations and the ownership of the means of production by the individual producers were assumed by Locke: 'Bourgeois society is thereby considered both historically, to some extent, and as a part of nature [naturgegeben], since on the one hand it appears as essentially determined by socially generalised natural constant that is human commodity production, but on the other hand ... is conceived as having developed from a situation where there was not yet the division of wage-labour and capital' (Rotermundt 1976, pp. 84-5).

26 Tully 1980. 
Tully's interpretation is especially interesting in this context as he explicitly criticised Macpherson's influential interpretation on which even Lohmann's analysis implicitly relied.

In Tully's opinion, Macpherson's interpretation leads to a paradoxical conclusion. It was precisely Locke's opponents - Grotius, Pufendorf and Filmer who proposed an exclusive rights theory and justified private property. Their theory employed natural law to protect exclusive rights by reducing it to the natural duty to abstain from another's property. According to Tully, Locke's theory was constructed in opposition to an unlimited rights theory; precisely the sort of theory that Marx took to be the typical justification of private property.

Locke, then, adopted not a concept of private property, but rather a concept of individual property. ${ }^{27}$ Following Driver, ${ }^{28}$ Tully further argued that the identification of Locke's concept of property with private property is a relatively new phenomenon: 'Early nineteenth century radicals fixed on Locke's theory of a natural property in the product of one's own labour and used it to legitimate revolt against the prevailing system of private property.' ${ }^{29}$ Tully also suggested that Marx interpreted Locke in the spirit of this radical tradition. According to Tully, Locke defined property as that which cannot be taken away without one's consent. But Locke's theory is not an unlimited rights theory because at the moment that cultivated fields and their products cease to be objects of use for a person, they cease to be her property, and the inclusive rights of others apply. ${ }^{30}$ Furthermore, Locke was by no means undermining the traditional obligations associated with property. On the contrary, he gave them a firm basis. Labour is not the sole means to entitle a person to the necessary means of support. In Locke's theory, there are two additional natural titles to property: charity and inheritance. $^{31}$

In addition to undermining the interpretation of Locke's theory as a justification of private property, Tully emphatically denied that Locke supposed the wage labour relationship to have existed in the state of nature. In the 'turfs' passage to which Macpherson refers, Locke was only assuming a master-servant relationship:

\footnotetext{
27 Tully 1980, p. 111.

28 Driver 1950, p. 91.

29 Tully 1980, p. 124.

30 Ibid.

31 Tully 1980, pp. 131-2.
} 
All that Locke assumes in the 'turfs' passage is a master-servant relation. It is not only not the wage relationship of capitalism, it is a fetter to the development of capitalism which was not supplanted until the late eighteenth century. ${ }^{32}$

In support of his interpretation, Tully provided two arguments: First, Locke assumed that a master-servant relation can only be established if a freeman has a choice not to become a servant. If, for some reason, there is no alternative available to him to support himself, then the relation cannot arise. ${ }^{33}$ The second argument follows directly from Locke's own definition of labour:

Since the labour of a person is defined as actions determined by the will of that person, it is logically impossible for an agent to alienate his labour. Therefore, what is sold by a freeman, and bought by another, is not his labour but, as Locke carefully writes, the 'Service he undertakes to do'.

A person directed in his activity like a wage worker by a capitalist would not be a servant but a slave or a vassal, and would be part of a relation 'to which Locke's servant is contrasted. ${ }^{34}$ Tully agreed with Macpherson that the introduction of money will, according to Locke's theory, lead to unequal possessions: 'As soon as money is introduced, some men begin to put more land under cultivation than is necessary for their uses and exchange the products they cannot use for money'. ${ }^{35}$ But even in this respect, Tully disagreed with Macpherson on one important question. Neither land nor money can possibly function as capital in Locke's theory: 'Land cannot be exchanged, only the products of it are alienable. There is no evidence in the Two Treatises that money functions as capital: it is simply hoarded. ${ }^{36}$

It is even more important to note that Locke thought that 'the acceptance of money brings with it the fall of man. ${ }^{37}$ People begin to desire more than they need, and as a consequence 'some men's desires are no longer coincident with the law of nature but, rather, drive them to overstep it'. ${ }^{38}$ In Locke's opinion, the introduction of money would lead to the violation of the law of nature if there

\footnotetext{
32 Tully 1980, p. 136.

33 Tully 1980, p. 138.

34 Tully 1980, p. 141.

35 Tully 1980 , p. 147.

36 Tully 1980, p. 149.

37 Tully 1980, p. 150.

38 Tully 1980, p. 151.
} 
were not some new rules to regulate the possession of land. Locke's solution to the problem of this new rule is civil law: 'The original proviso, that there is enough and as good [land] left in common for others, no longer obtains and, therefore, natural appropriation without consent is invalid. ${ }^{39}$

Tully's conclusion of his discussion of Locke's theory of property, then, is that Locke justified neither private property nor unlimited appropriation, but proposed instead 'a system in which private and common ownership are not mutually exclusive but mutually related; private ownership is the means of individuating the community's common property and is limited by the claims of all other members. ${ }^{40}$ As already pointed out, Tully briefly referred to Marx as a representative of the radical interpretation of Locke's theory as justifying private property. In a manuscript written between $1861-3$, Marx briefly mentioned Locke in a way that seems to support Tully's thesis. According to Marx, Locke represented two contrary conceptions. Locke presupposed both that the means of production are privately owned by every producer, and that the capitalist relations of production prevail - in Marx's opinion, these two contradictory presumptions were common to the whole succeeding political economy:

The general legal conception, from Locke to Ricardo, is therefore that of petty-bourgeois property, while the relations they actually describe belong to the capitalist mode of production. ${ }^{41}$

If this were Marx's only comment on Locke, one could probably interpret Marx as sharing the early nineteenth-century radicals' interpretation of Locke as defending capitalist private property - an interpretation which was followed by Macpherson. However, in the part of the manuscript that came to be known as Theories of Surplus Value [Theorien über den Mehrwert], which was written in the same period as the manuscript referred to earlier, Marx discussed Locke's theory in more detail, and in this manuscript Marx's conclusions did not remarkably differ from those reached by Tully. In Theorien, Marx wrote that Locke did not discuss any procedures of appropriation other than appropriation by labour; in Locke's theory, the right to property is always based on one's own labour. But the property in question is not private property; it is individual property:

\footnotetext{
39 Tully 1980, p. 153.

40 Tully 1980, p. 170.

41 Marx 1974-2004k, p. 471.
} 
What Locke therefore tries to show is not the contradiction - that property can nevertheless be acquired by other procedures than labour - but how, in spite of the common property in nature, individual property could be created by individual labour. ${ }^{42}$

Marx further acknowledged that in Locke's case personal labour is the limit of property, and that one cannot own more than one can personally make use of. Through the introduction of money, unequal possessions arise, but even then, Marx acknowledged that in Locke's theory the just measure of personal labour prevails. ${ }^{43}$ Marx even noted that Locke's theory was opposed to the demands of landlords. In Locke's opinion, the rent of land demanded by a landlord is no better than the interest received by any usurer.

Despite the fact that Marx thus clearly recognised that Locke's theory was not an affirmative theory of capitalist private property, he still emphasised the importance of Locke's conceptions to subsequent political economy. The latter shared with Locke the general idea that a title to property can only be created by personal labour. And the whole political economy succeeding Locke assumed that, even in bourgeois society, private property is based on personal labour:

Locke's view is all the more important because it was the classical expression of bourgeois society's ideas of right as against feudal society, and moreover his philosophy served as the basis for all the ideas of the whole of subsequent English political economy. ${ }^{44}$

The importance of Locke was further accentuated by the fact that Marx understood Locke to be the founder or predecessor of the labour theory of value: Locke comprehended value exclusively in terms of use value, but he also thought that labour made up by far the greatest part of the value of any useful thing - the rest is added by nature. ${ }^{45}$

Even though Macpherson was obviously drawing too daring consclusions from his reading of Locke's Two Treatises, he did pay attention to one important argument in Locke's theory that remains valid despite Tully's critique. Locke

\footnotetext{
$42 \quad$ Marx 1969a, p. 366.

43 Marx 1969a, pp. 366-7.

44 Marx 1969a, p. 367.

45 Marx 1969a, p. 342. Tully formulated Locke's conception of value as follows: 'Labour transforms nature into useful products, and so it is the source of value' (1980, p. 144). In Locke's theory, labour is thus associated with use value, with the usefulness of its products to humanity.
} 
not only assumed that it is labour that transforms nature's products into useful things. Because labour creates the greatest part of the value of a product, the common stock of useful things is increased by cultivating land and adding more labour to nature's products. Even though the justification of private property and the accumulation of capital cannot - as Tully has shown - possibly be actualised in Locke's theory, he did assume that by cultivating land and by creating a right of property in it, people contribute to the support of human life by increasing the value of things useful to humankind. Thus labour and the property associated with it are beneficial to humanity in creating the conditions for a better human life.

The same social benefits associated with labour and property were explicitly thought by Adam Smith, in The Wealth of Nations, ${ }^{46}$ to result from the increasing division of labour and from the increasing exchange of commodities - and from the establishment of private property closely connected with the division of labour. Once all unnatural barriers intervening with the free functioning of the economic laws of a commercial society have been removed, these laws will guarantee that the division of labour and exchange of commodities will lead to the general opulence of a nation, creating the possibilities of a human existence for the greatest number of its members. In Smith's opinion, it was the continuously growing wealth of a nation that guaranteed a decent living even for the lower ranks of people.

According to Smith, 'in that original state of things, which precedes both the appropriation of land and the accumulation of stock, the whole produce of labour belongs to the labourer. He has neither landlord nor master to share with him.47

In the natural law tradition, Smith regarded the property in one's own labour as the fundamental property right on which all other, more developed property rights are based: 'The property which every man has in his own labour, as it is the original foundation of all other property, so it is the most sacred and inviolable.48 Labour, also, is the ultimate measure of the value of commodities:

Labour alone, therefore, never varying in its own value, is alone the ultimate and real standard by which the value of commodities can at all times and places be estimated and compared. It is their real price; money is their nominal price. ${ }^{49}$

\begin{tabular}{ll}
\hline 46 & Smith 1970. \\
47 & Smith 1970, p. 167. \\
48 & Smith 1970, p. 225. \\
49 & Smith 1970, p. 136.
\end{tabular}


And further:

The real price of everything, what everything really costs to the man who wants to acquire it, is the toil and trouble of acquiring it ... What is bought with money or with goods is purchased by labour as much as what we acquire by the toil of our body ... Labour was the first price, the original purchase-money that was paid for all things. It was not by gold or silver, but by labour, that all the wealth of the world was originally purchased; and its value, to those who possess it, and who want to exchange it for some new productions, is precisely equal to the quantity of labour which it can enable them to purchase or command. ${ }^{50}$

In the original 'state of things, which precedes both the appropriation of land and the accumulation of stock, the whole produce of labour belongs to the labourer'. ${ }^{1}$ However, the situation is changed as soon as land becomes private property and stock is accumulated and the labourer becomes a wage labourer. Thereafter, one has to share the produce of one's labour with both the owners of stock and land. ${ }^{52}$ Both the introduction of money and the accumulation of stock are originally based on the demands of the increasing division of labour:

every prudent man in every period of society, after the first establishment of the division of labour, must naturally have endeavoured to manage his affairs in such a manner as to have at all times by him besides the peculiar produce of his own industry, a certain quantity of some one commodity or other, such as he imagined few people would be likely to refuse in exchange for the produce of their industry. ${ }^{53}$

In the original state of society, when every man produces for himself and there is seldom any exchange made, no stock need be accumulated. After the introduction of the division of labour, only a small part of those commodities that he himself makes use of are produced by him. Money, in the form of a commodity which is generally taken in exchange for the produce of other men's labour, is a convenient means of solving the problem of accumulation of stock and exchange of commodities.

\footnotetext{
50 Smith 1970, p. 133 .

$5^{1}$ Smith 1970, p. 167.

$5^{2} \quad$ Smith 1970, pp. 152, 168.

53 Smith 1970, pp. 126-7.
} 
Smith claimed that after the accumulation of stock and the establishment of private property of land, it is only natural that anyone interested in employing them is expected to get from the sale of their produce more than is sufficient to replace his stock. Otherwise, 'he could have no interest to employ a great stock rather than a small one, unless his profits were to bear some proportion to the extent of his stock'.54

The same is also true of the land that has become private property: 'The landlord demands a share of almost all the produce which the labourer can either raise, or collect from it.'55 The profits of stock and rent of land are, then, formed of a share of the produce of labour, which is the only thing that adds new value to things. On the other hand, the natural price of every commodity is, according to Smith, composed of three component parts forming its real price, wages, profits and rent, corresponding to the three sources of revenue, labour, stock and land:

In every society the price of every commodity finally resolves itself into some one or other, or all of those three parts; and in every improved society, all the three enter more or less, as component parts into the price of the far greater part of commodities. ${ }^{56}$

There is, however, yet a third conception of the determination of the value of commodities inherent in Smith's theory, the so-called labour command theory; the value of every commodity is determined by the amount of labour it can command or the value of the commodities with which it can be exchanged, and not directly by the amount of labour that has been necessary to produce it:

The value of any commodity, therefore, to the person who possessed it, and who means not to use or consume it himself, but to exchange it for other commodities, is equal to the quantity of labour which it enables him to purchase or command. ${ }^{57}$

54 Smith 1970, p. 151. Cf.: 'In exchanging the complete manufacture either for money, for labour, or for other goods, over and above what may be sufficient to pay the price of the materials, and the wages of the workmen, something must be given for the profits of the undertaker of the work who hazards his stock in this adventure. The value which the workmen add to the materials, therefore, resolves itself in this case into two parts, of which the one pays their wages, the other the profits of their employer upon the whole stock of materials and wages, which he advanced' (Ibid.).

55 Smith 1970, p. 168.

$56 \quad$ Smith 1970, p. 153 .

57 Smith 1970, p. 133 . 
It is this labour command conception that leads to the problematic conclusion that it is possible to exchange a certain amount of labour for a greater amount of labour.

The increasing division of labour and private property was legitimated by Smith by the just distribution of necessities of life it occasions and by the advancement of the interests of society. ${ }^{58}$ In The Theory of Moral Sentiments of 1759, Smith argued that the economic laws of a society - the 'invisible hand' even after the introduction of unequal possessions, will guarantee the same distribution of the necessities of life prevailing under the conditions of equal possessions of land:

They [the landlords] are led by an invisible hand to make nearly the same distribution of the necessaries of life, which would have been made, had the earth been divided into equal portions among all its inhabitants, and thus without intending it, without knowing it, advance the interest of the society, and afford means to the multiplication of the species. When Providence divided the earth among a few lordly masters, it neither forgot nor abandoned those who seemed to have been left out in the partition. These last too enjoy their share of all that it produces. ${ }^{59}$

In The Wealth of Nations, Smith argued that the increasing division of labour will lead to increasing opulence of the nation, an opulence extending to the lowest ranks of people:

It is the great multiplication of the productions of all the different arts, in consequence of the division of labour, which occasions, in a wellgoverned society, that universal opulence which extends itself to the lowest ranks of people. Every workman has a great quantity of his own work to dispose of beyond what he himself has occasion for; and every other workman being exactly in the same situation, he is enabled to exchange a great quantity of his own goods for a great quantity of, or what comes to the same thing, for the price of a great quantity of theirs. ${ }^{60}$

The increasing division of labour is considered to cause an increasing national wealth and a consequent increase in the real wages of labour. According to

\footnotetext{
$5^{8} \quad$ See Musgrave 1976, pp. 302-5.

59 Smith 1979, pp. 184-5.

6o Smith 1970, p. 115 .
} 
Smith, it is not the actual greatness of national wealth, but its continual increase which occasions a rise in the wages of labour: 'The liberal reward of labour, therefore, as it is the necessary effect, so it is the natural symptom of increasing national wealth'.61 This should be regarded as real advantage to a society:

Is this improvement in the circumstances of the lower ranks of the people to be regarded as an advantage or as an inconveniency to the society? The answer seems at first sight abundantly plain. Servants, labourers, and workmen of different kinds, make up the far greatest part of every great political society. But what improves the circumstances of the greater part can never be regarded as an inconveniency to the whole. No society can surely be flourishing and happy, of which the far greater part of the members are poor and miserable. It is but equity, besides, that they who food, clothe, and lodge the whole body of the people, should have such a share of the produce of their own labour as to be themselves tolerably well fed, clothed, and lodged. ${ }^{62}$

For Smith, the increasing division of labour, being the original moving force behind the increasing opulence of nations is

not originally the effect of any human wisdom, which foresees and intends that general opulence to which it gives occasion. It is the necessary, though very slow and gradual consequence of a certain propensity in human nature which has in view no such extensive utility: the propensity to truck, barter, and exchange one thing for another. ${ }^{63}$

The natural progress of opulence of nations is a guarantee of the possibility of 'human existence' in society. A continuous economic progress guarantees, even for the lower ranks of people, a decent and human existence, an existence equally good or even far better than in any primitive society which, by contrast, are more equal but miserably poor. ${ }^{64}$

61 Smith 1970, p. 176.

62 Smith 1970, p. 181.

63 Smith 1970, p. 117 .

64 Hont and Ignatieff 1983, pp. 1-2; see also Medick 1973, p. 281. Hans Medick interpreted the natural progress of opulence to be the result of a civilising dynamic caused by the artificial nature of needs of human beings (see Medick 1973, p. 251). He summarised Smith's conception of the natural state and the natural history of society as follows: 'With his 
As Istvan Hont and Michael Ignatieff ${ }^{65}$ have shown, the main question Smith attempted to answer in The Wealth of Nations was how exactly a commercial society with its marked inequality of property still satisfied the basic needs of those who laboured for wages:

Our argument is that the Wealth of Nations was centrally concerned with the issue of justice, with finding a market mechanism capable of reconciling inequality of property with adequate provision for the excluded. ${ }^{66}$

According to Hont and Ignatieff, ${ }^{67}$ Smith's unique solution to the problem was included in his conception of the 'productivity of modern forms of labour' (due to the division of labour) and his natural price model.

In Marx's opinion, it was Smith's greatest merit that he was the first to become sensitive to the problem of the origins of surplus value. By reconstructing Smith's labour theory of value, Marx showed that Smith was led to the conclusion that less labour can be exchanged for more labour, a conclusion contradicting his original law of value and the consequent postulate of equal exchange. From Marx's point of view, the interesting and problematic result of Smith's analysis was that once the simple exchange of commodities is transformed into exchange between wage labour and capital, the law of value no longer holds but instead is reversed:

It is Adam Smith's great merit that it is just in the chapters of Book I (chapters VI, VII, VIII) where he passes from simple commodity exchange and its law of value to exchange between materialised and living labour, to exchange between capital and wage-labour, to the consideration of profit and rent in general - in short, to the origin of surplus-value - that he feels some flaw has emerged. He senses that somehow - whatever the

model of an economic growth stimulated by the artificial nature of human needs, set free by the institutional guarantee of justice and regulated by the historical process in the form of his conception of the "Natural Progress of Opulence", Smith not only provided the benchmark of a normative natural history, with the aid of which he can identify, understand and criticise the empirical history of human beings, this simultaneously made available to him - as the telos of a "Natural Progress of Opulence" - the benchmark of a "state of nature", with the aid of which he analysed the society of his time, in order to teach it about itself' (Medick 1973, p. 250).

65 Hont and Ignatieff 1983 , p. 1.

66 Hont and Ignatieff 1983, p. 2.

67 Ibid. 
cause may be, and he does not grasp what it is - in the actual result the law is suspended: more labour is exchanged for less labour (from the labourer's standpoint), less labour is exchanged for more labour (from the capitalist's standpoint). His merit is that he emphasises - and it obviously perplexes him - that with the accumulation of capital and the appearance of property in land - that is, when the conditions of labour assume an independent existence over against labour itself - something new occurs, apparently (and actually, in the result) the law of value changes into its opposite. ${ }^{68}$

According to Marx, Smith was right in emphasising that a change was taking place, but he did not comprehend what really caused this change. ${ }^{69}$ And just as importantly, Smith did not understand that the exchange between wage labour and capital did not, in fact, violate the original law of value and equal exchange, even though as a result of this process of exchange the capitalist had indeed appropriated a surplus value. The ambivalence in Smith's theory of value resulted from his determination of the value of a product both by the amount of alien labour it can command and by the amount of labour that has been necessary to produce it. According to Marx, this led Smith to confuse two clearly distinct problems in analysing the exchange of commodities.

First, while emphasising the change caused by the introduction of the division of labour, exchange of products, and production for a market, Smith in fact problematised the social character of labour:

wealth no longer consists in the product of one's own labour, but in the quantity of the labour of others which this product commands, the social labour which it can buy, the quantity of which is determined by the quantity of labour it itself contains ... The emphasis here lies on the equalisation, brought about through the division of labour and exchange-value, of my labour with the labour of others, in other words, with social labour. ${ }^{70}$

Quantitatively, the relation of exchange is determined by the amount of labour that has been used in producing the commodities:

\footnotetext{
68 Marx 1969a, p. 87.

69 Marx was clearly exaggerating his case in claiming that Smith felt that a change took place in his argumentation concerning the relations of exchange once capital had been introduced. The contradictions of Smith's theory were reconstructed by Marx; obviously Smith was not conscious of them.

$70 \quad$ Marx 1969a, p. 76.
} 
Consequently, on this assumption the labourer is a mere seller of commodities, and one commands the labour of another only in so far as he buys the other's commodity with his commodity. He thus commands with his commodity only so much of the other's labour as is contained in his own commodity, since both exchange only commodities against each other, and the exchange-value of the commodities is determined by the labour-time or quantity of labour they contain. ${ }^{71}$

Second, Smith's analysis of the exchange relations between the commodity producers included another emphasis (even though Smith did not adequately comprehend it), namely, the relation between living and materialised labour. This relation seems to violate the rule of the exchange of equal amounts of labour objectified in commodities:

Secondly, however, a certain quantity of living labour is exchanged for an equal quantity of materialised labour, because, firstly, the living labour is materialised in a product, a commodity, which belongs to the labourer, and secondly, this commodity is in turn exchanged for another commodity which contains an equally large quantity of labour. ${ }^{72}$

The problem of the relation of exchange between living and materialised labour can be solved when it is realised that in a society where the means of production belong totally to one or several classes, and where the ability to work [Arbeitsvermögen] belongs to a different class, the class of workers, the product of labour in fact no longer belongs to the worker. If one demystifies Smith's conception of labour command and understands that it in fact refers to the relation between materialised and living labour, it can be interpreted to reveal the fact that the appropriation of surplus value begins at the moment when the means of labour belong to one class and the ability to work to another. In Marx's opinion, this differentiation of the social functions of the classes, or the separation of the means of labour from the ability to work, marks the beginning of capitalist society. ${ }^{73}$

On Marx's account, Smith had a notion that profits are nothing but a reduction from the value that labour adds to the material of work. The profits originate in the part of labour which is not paid, even though it is bought by the owner of capital:

\footnotetext{
$71 \quad$ Marx 1969a, p. 78.

72 Marx 1969a, p. 72.

73 Marx 1969a, p. 78.
} 
Adam Smith has thereby himself refuted the idea that the circumstances that the whole product of his labour no longer belongs to the labourer, that he is obliged to share it or its value with the owner of capital, invalidates the law that the proportion in which comodities exchange for each other, or their exchange-value, is determined by the quantity of labourtime materialised in them. ${ }^{74}$

The great merit of Smith was that he - without knowing it - emphasised the change that takes place in the relation of exchange after the introduction of capitalist production. However, Smith was mistaken in believing that the relation between materialised and living labour violates the rule of equal exchange and occasions a change in the determination of the relative value of commodities. $^{75}$

Marx's solution to the contradiction of classical political economy, as interpreted by him, was the introduction of the concept of labour power. All the contradictions inherent in the political economy concerning the origins of profits and surplus value could be solved once the specific character of the commodity 'labour power' was developed: labour power has both a use value and an exchange value like any other commodity, the only difference being that its specific use value is its ability to create new value. Thus it was possible for Marx to show that the exchange between materialised labour and living labour follows the same rule of equal exchange as any exchange of commodities in a society of commodity production, that is to say, in a society where private labour becomes social only through exchange, and where the products of labour only have use value to the buyers and exchange value to the sellers of commodities.

Marx's critique and analysis of the capitalist mode of appropriation and private property in Capital and in the Grundrisse in particular was a direct comment on the anomalies he had identified in Smith's theory of value. According to Marx, in capitalism the right to property is transformed from one based on one's own labour into a right to appropriate the products of alien labour, and to a duty to respect one's own labour and its products as belonging to another. Marx stated that in capitalism the exchange of equivalents, reflected in the legal rules governing private property, seems to be a mere appearance:

$74 \quad$ Marx 1969a, pp. 79-8o.

75 Marx 1969a, p. $5^{2}$. 
The exchange of equivalents, however, which appeared as the original operation, an operation to which the right of property gave legal expression, has become turned round in such a way that the exchange by one side is now only illusory, since the part of capital which is exchanged for living labour capacity, firstly, is itself alien labour, appropriated without equivalent, and, secondly, has to be replaced with a surplus by living labour capacity, is thus in fact not consigned away, but merely changed from one form into another. The relation of exchange has thus dropped away entirely, or is a mere semblance. ${ }^{76}$

The relation between capital and labour only appears to be a relation of equivalents because, in fact, the result of exchange is the appropriation of surplus labour, and the capital which is exchanged against labour power is already a result of an earlier process of appropriation of alien labour or its product, and is consequently not based on one's own labour as presupposed by the original idea of the right to property. However, to speak of exchange as 'pure appearance' is somewhat misleading. The relation between capital and labour power is, in reality, one of exchange. The relation is only one of appearance if one considers not a single act of exchange but the total relation of exchange between the class of capitalists and the class of wage workers. ${ }^{77}$ The relation is, then, only one of appearance - it could be interpreted - because the accumulated capital is already (in total) a result of the previous appropriation of surplus value. It does not in any way consist of the materialised labour of its owner. Further, on Marx's account, the whole act of exchange belongs to the sphere of circulation, which ignores the 'deeper' process of production as the consumption of use values and the creation of new value by labour power.

While discussing the transformation of surplus value into capital in Capital, Marx also analysed the problems of the capitalist form of appropriation. The critique of the legal rules of capitalist appropriation and private property is, in a way, completed as soon as all the capital is shown to originate from the surplus value produced previously by the wage worker. The last legitimatory argument defending the right to private property as a right to the products of one's own labour loses its rationale: "The ownership of past unpaid labour is thenceforth the sole condition for the appropriation of living unpaid labour on a constantly increasing scale. ${ }^{78}$

\footnotetext{
$76 \quad$ Marx 1973, p. 458.

77 Clarke 1982, p. 84.

78 Marx 1974-2004l, p. 582.
} 
As soon as the production of commodities becomes generalised, labour power takes the form of a commodity too. And consequently, the law of appropriation is reversed:

in so far as each single transaction invariably conforms to the laws of the exchange of commodities, the capitalist buying labour-power, the labourer selling it, and we will assume at its real value; in so far as all this is true, it is evident that the laws of appropriation or of private property, laws that are based on the production and circulation of commodities, become by their own inner and inexorable dialectic changed into their very opposite. ${ }^{79}$

In the Grundrisse, Marx formulated the result of this transformation in similar terms as in Capital: the exchange takes place only in appearance. ${ }^{80}$ In Capital, he stated that the relation of exchange between the capitalist and the worker is thus a mere appearance belonging to the process of circulation. It is a pure form, alien to the contents of this process and mystifying them:

The ever repeated purchase and sale of labour-power is now the mere form; what really takes place is this - the capitalist again and again appropriates, without equivalent, a portion of the previously materialised labour of others, and exchanges it for a greater quantity of living labour. ${ }^{81}$

The right to property which was thought to be originally based on the products of one's own labour is thus in reality reversed into the right to appropriate alien labour and its products without a mutual equivalent:

Now, however, property turns out to be the right, on the part of the capitalist, to appropriate the unpaid labour of others or its product, and to be the impossibility, on the part of the labourer, of appropriating his own product. The separation of property from labour has become the necessary consequence of a law that apparently originated in their identity. 82

\footnotetext{
79 Ibid.

8o $\quad$ Marx 1973, p. $45^{8}$.

81 Marx 1974-2004l, pp. 582-3.

$82 \quad$ Marx 1974-2004l, p. 583.
} 
The identity of property and labour, as postulated by the natural law theory and its followers, classical political economists, is thus broken and reversed into a dissociation of property and labour.

Nevertheless, Marx wanted to emphasise that this new capitalistic form of appropriation does not violate the original law of commodity exchange. Quite the contrary, it results from the observance of this rule. The whole secret of the transformation of the law of appropriation consists of the fact that even if the process of the exchange of commodities is also conditioned by the difference in use values, it does not tell us anything about the (productive) consumption of commodities, which only begins after the act of exchange has been completed. ${ }^{83}$

To Kautsky and other Marxists of the Second International, capitalism was mainly to be blamed because it does not respect the right of the labourer to the products of her or his labour. Marx's critique of capitalist private property was more developed and complicated. First, Marx continuously emphasised that the capitalist form of appropriation does not violate the rule of commodity exhange. The mutual freedom and equality of commodity owners is respected even in the relation between capital and wage labour. Second, Marx's analysis in fact implicitly included a critique of such a radical version of the natural rights theory, which was later adopted by traditional Marxism. In Marx's opinion, the title to property is never constituted by humankind's productive relation to nature.

Marx did not stop at the point of showing how appropriation is, in fact, transformed into its opposite form in capitalism. He also explained why classical political economy insisted on labour remaining the basis for the right to property even in bourgeois society. The original appropriation of commodities, their production, takes place outside the sphere of circulation. Within the process of circulation, commodities can only be appropriated through exchange, that is, the appropriation of the products of alien labour can only take place through the alienation of one's own labour. Consequently, the only way to appropriate commodities seems to be exclusively through one's own labour:

It is true that the production of commodities does not fall within the simple process of exchange as it unfolds at the various moments of circulation. Commodities are rather implied as finished use values ... The ori-

83 Marx 1976, p. 731. Cf.: 'In present bourgeois society as a whole, this positing of prices and their circulation etc. appears as the surface process, beneath which, however, in the depths, entirely different processes go on, in which this apparent individual equality and liberty disappear' (Marx 1973, p. 247). 
gination of commodities, and so also the original process of their appropriation, lies, therefore, beyond circulation. ${ }^{84}$

Because the original appropriation of commodities does not belong to the sphere of circulation, the process in which the private property owners are born is postulated as being based on the original appropriation of nature's products through labour:

How they became private proprietors, i.e. how they appropriated objectified labour, is a circumstance which appears not to fall within the examination of the simple circulation at all. ${ }^{85}$

A commodity can be thought only to be a product of one's own labour, because the process through which the owners have become owners of commodities takes place, in a way, behind the backs of the exchangers:

And since from its standpoint, alien commidities, i.e. alien labour, can be appropriated only through the alienation of one's own labour, the pre-circulation process of commodity appropriation necessarily appears from this standpoint as appropriation through labour, and just as the latter is appropriation of the products of Nature, it equally appears as the juridical title to property. ${ }^{86}$

The process of circulation is a 'pure appearance' because it is based on conditions which are not set by it, but which are given in relation to it:

Considered in itself, circulation is the mediation of presupposed extremes. But it does not posit these extremes. As the totality of mediation it itself must be mediated, as total process. That is why its immediate being is pure semblance. It is the phenomenon of a process running behind its back. ${ }^{87}$

According to Marx, the right to private property is considered by all the modern economists since John Locke to be based on one's own labour; the title to property is thought to be a result of the objectification of one's own labour.

\footnotetext{
84 Marx 1974-2004i, pp. 461-2.

85 Marx 1974-2004i, p. 462.

86 Ibid.

$87 \quad$ Marx 1974-2004i, p. 479 .
} 
The situation is, however, paradoxical, because the problem of the legitimation of property is actualised only in a society based on the division of labour and the production of commodities, in a society where labour becomes social only through exchange. The right to private property and the law of appropriation valid in simple commodity production are thought to be valid in a bourgeois society too. They are transplanted into a capitalist society without recognising that their realisation is possible only in the 'golden period' of simple commodity production, in a state of society characterised by the ownership of the means of production by every individual producer. The right to private property in a bourgeois society is postulated into a historical period in which the conditions of this society were not at all present:

That would produce the strange result that the truth about the bourgeois society's law of appropriation would have to be transferred to a time when this society itself did not exist, and the basic law of property, to the time of propertylessness. ${ }^{88}$

According to Marx's analysis, there is thus a paradox in the thinking of political economy: private property in a bourgeois society is legitimated by the appropriation of nature's products by labour, by the eternal relation of humans to nature. This is a further consequence of the postulate that the right to property is read back into a hypothetical state of nature preceding the capitalist production of commodities and private property. The laws of bourgeois society are thus thought to be natural laws which are eternally valid. And consequently, the freedom and equality of every commodity owner and producer associated with private property and exchange of commodities are regarded as the natural properties of humankind.

Marx argued that the ideas of freedom and equality of individuals as bourgeois ideas of justice in reality have their origin in the sphere of circulation, in the exchange of exchange values. As exchangers of commodities, individuals are in fact free and equal:

From the act of exchange itself, each of the subjects returns upon himself as the ultimate end of the entire process, as the dominant subject. In this way, therefore, the subject's complete freedom is realized. ${ }^{89}$

88 Marx 1974-2004i, p. 463.

89 Marx 1974-2004i, p. 471. 
Every subject is only an exchanger of commodities, and as such all are equal: 'As subjects of exchange, their relation is therefore that of equality'.90 Every individual recognises the other as an owner of a commodity, as an autonomous individual, and does not try to use force to seize the property of another. The act of exchange presupposes common consent even though both partners of exchange are only realising their egoistic interests: 'The general interest is precisely the generality of self-seeking interests'. ${ }^{91}$ Marx summarised his ideas about equality and freedom by saying that the economic form (exchange) determines the subjects as equal while the contents of the process (the material needs which drive individuals to exchange with each other) determine their freedom. The exchange of exchange values is thus the 'productive basis of freedom and equality':

Equality and freedom are thus not only respected in exchange based on exchange values but, also, the exchange of exchange values is productive, the real basis of all equality and freedom. As pure ideas they are merely the idealized expressions of this basis; as developed in juridical, political, social relations, they are merely this basis to a higher power. ${ }^{92}$

In order to express the economic relation, the relation between capital and wage labour as a legal relation, as a relation of property, all we have to do according to Marx - is analyse the process of value increase as a process of appropriation. ${ }^{93}$

The right to property is in capitalism, in fact, based on alien labour:

For example, the fact that surplus labour is posited as surplus value of capital means that the worker does not appropriate the product of his own labour; that it appears to him as alien property; inversely, that alien labour appears as the property of capital. This second law of bourgeois property, the inversion of the first ... becomes just as established in law as the first. The first is the identity of labour with property; the second, labour as negated property, or property as negation of the alien quality of alien labour. ${ }^{94}$

\footnotetext{
$90 \quad$ Marx 1973, p. 241.

91 Ibid.

$92 \quad$ Marx 1973, p. 245.

93 Marx 1973, p. 469.

94 Marx 1973, pp. 469-7o.
} 
Still, within the sphere of circulation the capitalist can only acquire the title to property, to an alien commodity by giving away her or his own commodity. And her or his own commodity can only be thought to have been produced by her or his own work. Both the capitalist and the wage worker are free and equal commodity exchangers who own their own commodities - money capital and labour power, respectively - and can only acquire the other's property by exchange and mutual consent. ${ }^{95}$

As has already been pointed out, private property and the ideas of freedom and equality are paradoxically thought by classical political economy to have their full validity in the golden period, in the postulated state of nature preceding bourgeois society. This idea is based on the contradictory assumptions of both the identity of producer and appropriator ('simple commodity production') and the generalisation of commodity relations, relations of the exchange of exchange values. ${ }^{96}$ The whole ambiguity follows - as seen from Marx's critical perspective - from the identification of abstract with concrete labour, which leads to the identification of social relations with the relations of nature. In the classical thinking, labour constitutes both the intersubjective relations of exchange and humanity's relation to nature, the original appropriation of nature's products. By mixing nature with labour, humans appropriate nature's products and achieve a title to property. By objectifying our labour, we

95 Cf. 'In order that these objects may enter into relation with each other as commodities, their guardians must place themselves in relation to one another, as persons whose will resides in those objects, and must behave in such a way that each does not appropriate the commodity of the other, and part with his own, except by means of an act done by mutual consent. They must therefore mutually recognise in each other the rights of private proprietors. This juridical relation, which thus expresses itself in a contract, whether such contract be part of a developed legal system or not, is a relation between two wills, and is but the reflex of the real economic relation between the two. It is this economic relation that determines the subject-matter comprised in each such juridical act' (Marx 1974-2004l, p. 55).

96 The mistake of the utopian socialists (especially Proudhon) resulted from similar contradictory assumptions. According to Marx, they wanted to preserve the relations of commodity exchange and private property but get rid of their consequences, capital and money: 'What this reveals, on the other side, is the foolishness of those socialists (... who want to depict socialism as the realization of the ideals of bourgeois society articulated by the French revolution) who demonstrate that exchange and exchange value etc. are originally (in time) or essentially (in their adequate form) a system of universal freedom and equality, but that they have been perverted by money, capital, etc ... It is just as pious as it is stupid to wish that exchange value would not develop into capital, nor labour which produces exchange value into wage labour' (Marx 1973, p. 248). 
create a common denominator for our and others' products, thus constituting the exchange relations. As products of our very labour, commodities are alienable and can be exchanged with each other. People enter into social relations as private property owners.

According to Marx's own self-understanding, the discovery of the dual character of labour, the distinction between abstract and concrete labour, was the 'great discovery' which made it possible for him to criticise and solve the anomalies of classical political economy. ${ }^{97}$ It still is labour, but now abstract labour, a special social form of labour, which constitutes the social relations of commodity exchangers. Labour as concrete labour produces use values and constitutes humanity's relation to nature, our exchange of substance with nature. More concretely, the analyses of the dual character of labour and the production process of capital made it possible to show how surplus value is created 'both outside and inside circulation'; the specific use value of labour power is to create new value which is materialised in the production process, whereas the exchange between capital and wage labour still follows the rule of equal exchange. The value of labour power (and the wage of the wage labourer in the ideal case) is determined by the costs of its reproduction. Even though fully compensating the wage worker, the capitalist is still able to appropriate surplus value. Marx's discovery also made it possible for him to understand how capitalist private property - which seems to be based exclusively on the labour of its owner - in reality, is based on the appropriation of the products of alien labour. The unity of property and labour is destroyed. The pronounced inequality of possessions cannot be justified by the general well-being of the whole nation, as Smith and Locke were inclined to think. As Marx understood it, in a bourgeois society, accumulation of misery takes place alongside the accumulation of riches.

$97 \quad$ Marx 1867; cf. Marx 1974-2004l, p. 51. 